\title{
Biodiesel Synthesis from Rapeseed Oil in the Presence of Sodium and Potassium Hydroxides
}

\author{
Valdis Kampars ${ }^{1}$, Kristaps Māliņš ${ }^{2}$, Tatjana Rusakova ${ }^{3}$, Zane Šustere ${ }^{4}$, Jānis Brinks ${ }^{5}$ \\ ${ }^{1-5}$ Riga Technical University
}

\begin{abstract}
Biodiesel is produced by methanolysis or ethanolysis of triglycerides, and there are many factors affecting the transesterification process. The most important variables of the transesterification reaction are as follows: quality of the oil, catalyst type, concentration of catalyst, molar ratio of alcohol to oil, temperature and reaction time. The literature studies show that there is not a generally accepted procedure for the characterisation of transesterification reactions results and catalyst formulation activity. Therefore, even the evaluation of the usability of the most utilised industrial catalysts (sodium hydroxide and potassium hydroxide) is inconsistent. The experimental investigations of the transesterification reactions of high quality rapeseed oil in the presence of the above mentioned catalysts by change of all the variables allow us to regard two different characteristics of each reaction (reaction yield and process yield) that has to be determined. The comparison of these two characteristics gives a new instrument for classification of catalyst formulations. In the case of high quality rapeseed oil, sodium hydroxide and potassium hydroxide have shown a similar activity. Sodium hydroxide is more preferable when the concentration area of the used catalysts is low, but potassium hydroxide - at the high concentration area of catalysts.
\end{abstract}

Keywords: biodiesel, homogeneous basic catalysts, evaluation of catalyst formulation

\section{INTRODUCTION}

Today fossil fuels take up $80 \%$ of the primary energy consumed in the world and up to $95 \%$ of the energy consumed in the transport sector. It causes enormous greenhouse gas emission, global warming and climate changes [1]. The increasing global demand for energy and especially for fuels in the transport sector, depletion of fossil fuel reserves, climate changes and insecurity of import have necessitated the search for the alternative and renewable liquid fuels. Fuels derived from biomass sources are environmentally friendly, and expanding their use is a very promising way for reducing the petroleum-based fuel proportion in transport and reducing the greenhouse gas emissions from road and non-road vehicles. Biofuels are classified as biofuels of first, second and thirdgenerations. The most well-known first-generation biofuel is biodiesel. It is a renewable fuel produced by the transesterification of vegetable oils, recycled cooking greases and animal fats. The process of transesterification of triglycerides takes place by the usage of methanol or ethanol and different catalysts (homogenous basic, homogenous acid, heterogenous basic, heterogenous acid or enzymatic catalysts) [2-10]. The yield of the desired product as well as economic and ecologic aspects of biodiesel production depend on the quality of the catalyst [11] and the other transesterification parameters such as the quality of oil, catalyst formulation, amount of catalyst, molar ratio of methanol to oil, reaction temperature and reaction time. The most popular catalysts are sodium hydroxide and potassium hydroxide [12,13]. In this study we have used a high quality rapeseed oil for the investigation of biodiesel synthesis by the use of sodium hydroxide and potassium hydroxide as catalysts. The goal of this research work is to find new aspects in the evaluation of the specific character of the two most popular homogeneous basic catalysts.

\section{MATERIALS AND METHODS}

The experiments were carried out by variation of all the parameters of the reaction such as: methanol/oil molar ratio, reaction time, type of the catalyst and its concentration. Refined high-quality rapeseed oil was purchased from the local producer JSC Iecavnieks. Methanol (98\%), sodium (98\%) and potassium (98\%) hydroxides were purchased from Aldrich. The following reaction procedure was implemented: $100 \mathrm{~g}$ of the rapeseed oil were weighted in $250 \mathrm{~mL}$ three neck round flask with a condenser and mixer. After preheating of the oil, the corresponding amount of methanol-catalyst solution was added by intensive mixing (600 rpm). Before the adding of reagents and during the reaction, keeping of the reaction mixture at the given temperature within limit $\pm 1^{\circ} \mathrm{C}$ was ensured. The time was measured by a chronometer, and the starting point was the moment, when all the methanol solution was added. After the defined period from the adding of the reagents to the rapeseed oil at the selected temperature, the reaction was stopped by diluting the reaction mass with approximately double amount of water containing hydrochloric acid in the necessary amount for alkali neutralization. After 10 minutes of centrifugation at $9000 \mathrm{rpm}$, the top phase was separated and the methanol from that phase was removed by rotary evaporation within 10 minutes under pressure of 9 mbar. The weight of the obtained product and the content of fatty acid methyl esters (FAME) were determined. The FAME content was determined by FTIR and compared with the results of HPLC and GC. Chromatography analysis were performed by the use of Waters HPLC-MS and Analytical Controls All-in-one Biodiesel Analyser. Spectroscopy analysis were performed on the instruments Perkin Elmer Spectrum 100 FT-IR spectrometer with HATR accessory and Spectrum 100N FTNIR. In order to determine the concentration of FAME, absorbances at $1435 \mathrm{~cm}^{-1}$ and $6005 \mathrm{~cm}^{-1}$ were measured. 


\section{RESULTS AND DISCUSSION}

The two most commonly used alkaline catalysts from the wide range of potential alkaline metal hydroxides, alkoxides and carbonates are sodium hydroxide and potassium hydroxide [12-17]. Both of them are water forming catalysts $[18,19]$ and from the material cost perspective the sodium hydroxide is the catalyst of a better choice [4, 16, 17]; nevertheless, the potassium hydroxide may have some other advantages [20]. As the obtained experimental characteristics obviously depend not only on catalyst formulation, but also on the other variables (quality of the feedstock, methanol-to-oil molar ratio, temperature and reaction time), it is very difficult to evaluate the advantages and disadvantages of the defined catalyst formulation. In order to elaborate a method for comparison of catalyst formulations in this research work we have investigated the transesterification reactions of highquality rapeseed oil with methanol in the presence of sodium and potassium hydroxides by the change of all the reaction variables. For the characterisation of the selected catalyst formulation we have used two different characteristics:

Reaction yield (\% of FAME in the ester layer) is the ester content in the oil layer determined by chromatography or spectroscopy, after the two phases are formed without the separation of the phases.

Process yield (yield of FAME) is the ester content in the desired product determined by chromatography or spectroscopy after the isolation and purification of the oil phase, and the determination of its mass $\left(\mathrm{m}_{\text {isol }}\right)$ can be calculated by multiplying the reaction yield with $\mathrm{m}_{\mathrm{isol}} / \mathrm{m}_{\text {theor }}$, where $\mathrm{m}_{\text {theor }}$ is the stoichiometric (theoretical) mass of FAME.

The determined characteristics of the investigated reactions are presented in Table 1 and Table 2. As it follows from the obtained results, both catalysts allow to perform the transesterification with a high reaction yield and high process yield. The comparison of the results for both catalyst formulations in processes with the same methanol-to-oil molar ratio, reaction temperature and time does not give the possibility to come out in favour for some of them. Within the experimental errors, both reaction yield and process yield show that the activity of sodium hydroxide and potassium hydroxide is approximately the same. The comparison of the process yield and the reaction yield for each catalyst individually, we can conclude that there is some difference between the two investigated catalysts. In case of sodium hydroxide, the concentration of catalyst was changed from 0.2 to5.0 wt.\% of oil, when we compared all the obtained results (Fig. 1), the correlation was not good $\left(r^{2}=0.88\right)$.

When we analysed the results of the reactions for which the amount of catalyst varied only from 0.2 to $5.0 \mathrm{wt} . \%$ of oil, the correlation considerably improved, thus, indicating that the soap formation at the high catalyst concentration area made difficult the separation of two layers and the process yield decreased. On the basis of the correlation of the reaction yield and process yield we can conclude that the higher limit for a linear area in the case of sodium hydroxide is approximately $1.5 \mathrm{wt} . \%$ of oil and only in this area it is possible to have the high process yield. The analysis of correlation of the reaction yield and process yield for potassium hydroxide (Fig. 2) shows that the correlation of all results in the catalyst concentration area of $1-4$ wt. $\%$ of oil is better $\left(r^{2}=0.922\right)$ and only slightly improves $\left(\mathrm{r}^{2}=0.94\right)$ by reducing this area to 1 2.5 wt. $\%$ of oil.

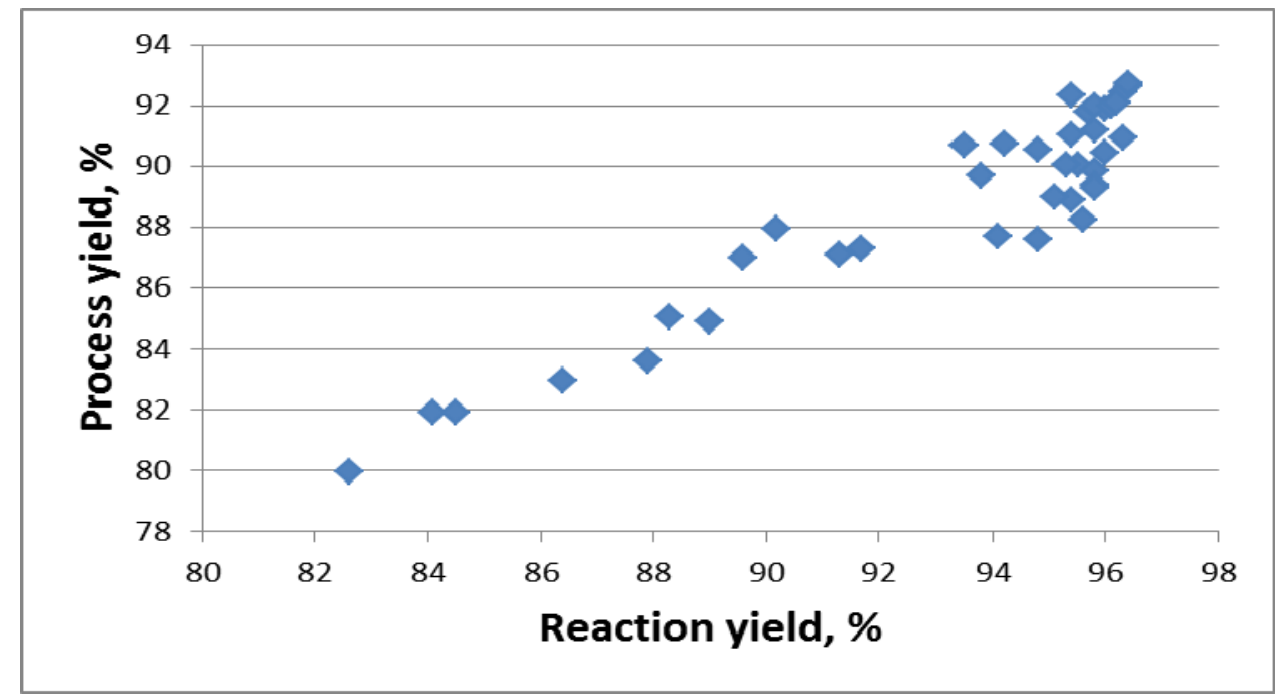

Fig. 1. Correlation between the reaction yield and process yield of transesterification (catalyst - sodium hydroxide) 
TABLE 1

TRANSESTERIFICATION BY USING NAOH AS A CATALYST

\begin{tabular}{|c|c|c|c|c|c|c|c|}
\hline No. & Time, min & $\begin{array}{c}\text { Catalyst, } \\
\text { wt.\% of oil }\end{array}$ & $\begin{array}{l}\text { Molar ratio of } \\
\text { methanol to oil }\end{array}$ & $\begin{array}{c}\text { Temperature, } \\
{ }^{\circ} \mathrm{C}\end{array}$ & $\begin{array}{l}\text { Reaction } \\
\text { yield, } \%\end{array}$ & $\begin{array}{l}\text { Weight, } \\
\text { g }\end{array}$ & $\begin{array}{c}\text { Process yield, } \\
\%\end{array}$ \\
\hline 1 & 60 & 0.9 & 3.2 & 60 & 86.4 & 96.0 & 82.94 \\
\hline 2 & 180 & 0.9 & 3.2 & 60 & 89.6 & 97.1 & 87 \\
\hline 3 & 60 & 0.9 & 3.5 & 60 & 89.0 & 95.4 & 84.91 \\
\hline 4 & 180 & 0.9 & 3.5 & 60 & 90.2 & 97.5 & 87.95 \\
\hline 5 & 60 & 0.9 & $4.0-6.0$ & 60 & 96.4 & 96.1 & 92.64 \\
\hline 6 & 180 & 0.9 & $4.0-6.0$ & 60 & 95.4 & 96.8 & 92,35 \\
\hline 7 & 60 & 0.2 & 4.0 & 60 & 84.1 & 97.4 & 81.91 \\
\hline 8 & 180 & 0.2 & 4.0 & 60 & 91.3 & 95.4 & 87.1 \\
\hline 9 & 60 & 0.3 & 4.0 & 60 & 88.3 & 96.3 & 85.03 \\
\hline 10 & 180 & 0.3 & 4.0 & 60 & 93.5 & 97.0 & 90.7 \\
\hline 11 & 60 & 0.5 & 4.0 & 60 & 94.2 & 96.3 & 90.72 \\
\hline 12 & 180 & 0.5 & 4.0 & 60 & 94.8 & 95.5 & 90.53 \\
\hline 13 & 60 & 0.6 & 4.0 & 60 & 95.7 & 95.9 & 91,78 \\
\hline 14 & 180 & 0.6 & 4.0 & 60 & 96.3 & 96.0 & 92.45 \\
\hline 15 & 60 & 0.5 & 4.0 & 30 & 82.6 & 96.8 & 79.96 \\
\hline 16 & 180 & 0.5 & 4.0 & 30 & 87.9 & 95.1 & 83.59 \\
\hline 17 & 60 & 0.5 & 4.0 & 40 & 84.5 & 96.9 & 81.88 \\
\hline 18 & 180 & 0.5 & 4.0 & 40 & 91.7 & 95.2 & 87.3 \\
\hline 19 & 60 & 0.5 & 4.0 & $50-80$ & 93.8 & 95.6 & 89.67 \\
\hline 20 & 180 & 0.5 & 4.0 & $50-80$ & 95.4 & 95.4 & 91.01 \\
\hline 21 & 60 & 0.9 & 4.0 & 60 & 95.8 & 95.2 & 91.2 \\
\hline 22 & 180 & 0.9 & 4.0 & 60 & 96.0 & 95.7 & 91.87 \\
\hline 23 & 60 & 1.2 & 4.0 & 60 & 95.8 & 96.0 & 92 \\
\hline 24 & 180 & 1.2 & 4.0 & 60 & 96.1 & 95.7 & 91,97 \\
\hline 25 & 60 & 1.5 & 4.0 & 60 & 96.4 & 96.2 & 92.74 \\
\hline 26 & 180 & 1.5 & 4.0 & 60 & 96.2 & 95.7 & 92.06 \\
\hline 27 & 60 & 1.8 & 4.0 & 60 & 95.5 & 94.3 & 90.06 \\
\hline 28 & 180 & 1.8 & 4.0 & 60 & 96.3 & 94.4 & 90.91 \\
\hline 29 & 60 & 2.1 & 4.0 & 60 & 96.0 & 94.2 & 90.43 \\
\hline 30 & 180 & 2.1 & 4.0 & 60 & 95.3 & 94.5 & 90,06 \\
\hline 31 & 60 & 2.5 & 4.0 & 60 & 95.8 & 93.8 & 89.86 \\
\hline 32 & 180 & 2.5 & 4.0 & 60 & 95.4 & 93.2 & 88.91 \\
\hline 33 & 60 & 3.0 & 4.0 & 60 & 95.8 & 93.3 & 89.38 \\
\hline 34 & 180 & 3.0 & 4.0 & 60 & 95.8 & 93.2 & 89.27 \\
\hline 35 & 60 & 4.0 & 4.0 & 60 & 95.1 & 93.6 & 89.01 \\
\hline 36 & 180 & 4.0 & 4.0 & 60 & 94.1 & 93.2 & 87.7 \\
\hline 37 & 60 & 5.0 & 4.0 & 60 & 95.6 & 92.3 & 88.24 \\
\hline 38 & 180 & 5.0 & 4.0 & 60 & 94.8 & 92.4 & 87.59 \\
\hline
\end{tabular}


TABLE 2

TRANSESTERIFICATION BY USING KOH AS A CATALYST

\begin{tabular}{|c|c|c|c|c|c|c|c|}
\hline No. & Time, min & $\begin{array}{c}\text { Catalyst, } \\
\text { wt.\% of oil }\end{array}$ & $\begin{array}{l}\text { Molar ratio of } \\
\text { methanol to oil }\end{array}$ & $\begin{array}{c}\text { Temperature, } \\
{ }^{\circ} \mathrm{C}\end{array}$ & $\begin{array}{l}\text { Reaction } \\
\text { yield, \% }\end{array}$ & $\begin{array}{l}\text { Weight, } \\
\text { g }\end{array}$ & $\begin{array}{c}\text { Process yield, } \\
\%\end{array}$ \\
\hline 1 & 60 & 2.0 & $3.2-3.5$ & 60 & 93.2 & 94.7 & 88.26 \\
\hline 2 & 180 & 2.0 & $3.2-3.5$ & 60 & 93.7 & 95.3 & 89.3 \\
\hline 3 & 60 & 2.0 & $4.0-4.5$ & 60 & 94.1 & 96.1 & 90.43 \\
\hline 4 & 180 & 2.0 & $4.0-4.5$ & 60 & 94.8 & 95.8 & 90.82 \\
\hline 5 & 60 & 2.0 & $5.0-6.0$ & 60 & 95.3 & 95.3 & 90.82 \\
\hline 6 & 180 & 2.0 & $5.0-6.0$ & 60 & 95.8 & 94.5 & 90.53 \\
\hline 7 & 60 & 2.0 & $7.0-8.0$ & 60 & 96.1 & 95.1 & 91.39 \\
\hline 8 & 180 & 2.0 & $7.0-8.0$ & 60 & 96.4 & 94.9 & 91.48 \\
\hline 9 & 60 & 0.5 & 4.0 & 60 & 85.2 & 95.6 & 81.45 \\
\hline 10 & 180 & 0.5 & 4.0 & 60 & 88.5 & 96.3 & 85.23 \\
\hline 11 & 60 & 1.0 & 4.0 & 60 & 93.0 & 94.5 & 87.89 \\
\hline 12 & 180 & 1.0 & 4.0 & 60 & 93.4 & 94.7 & 88.45 \\
\hline 13 & 60 & 1.3 & 4.0 & 60 & 94.9 & 96.3 & 91.39 \\
\hline 14 & 180 & 1.3 & 4.0 & 60 & 95.3 & 94.8 & 90.34 \\
\hline 15 & 60 & 2.5 & 4.0 & 60 & 95.5 & 94.7 & 90.44 \\
\hline 16 & 180 & 2.5 & 4.0 & 60 & 95.7 & 94.9 & 90.82 \\
\hline 17 & 60 & 4.0 & 4.0 & 60 & 96.2 & 94.3 & 90.72 \\
\hline 18 & 180 & 4.0 & 4.0 & 60 & 94.4 & 96.7 & 91.29 \\
\hline 19 & 60 & 2.0 & 4.0 & $30-40$ & 94.6 & 95.4 & 90.25 \\
\hline 20 & 180 & 2.0 & 4.0 & $30-40$ & 95.3 & 94.3 & 89.87 \\
\hline 21 & 60 & 2.0 & 4.0 & $50-60$ & 95.3 & 95.8 & 91.3 \\
\hline 22 & 180 & 2.0 & 4.0 & $50-60$ & 95.6 & 95.1 & 90.92 \\
\hline 23 & 60 & 2.0 & 4.0 & $70-80$ & 96.3 & 94.9 & 91.39 \\
\hline 24 & 180 & 2.0 & 4.0 & $70-80$ & 96.5 & 94.3 & 91.0 \\
\hline 25 & 60 & 0.7 & 4.0 & 60 & 95.6 & 95.1 & 90.92 \\
\hline 26 & 180 & 0.7 & 4.0 & 60 & 95.8 & 95.7 & 91.68 \\
\hline 27 & 60 & 1.6 & 4.0 & 60 & 95.7 & 96.0 & 91.87 \\
\hline 28 & 180 & 1.6 & 4.0 & 60 & 96.0 & 96.1 & 92.26 \\
\hline 29 & 60 & 1.9 & 4.0 & 60 & 95.9 & 95.0 & 91.1 \\
\hline
\end{tabular}

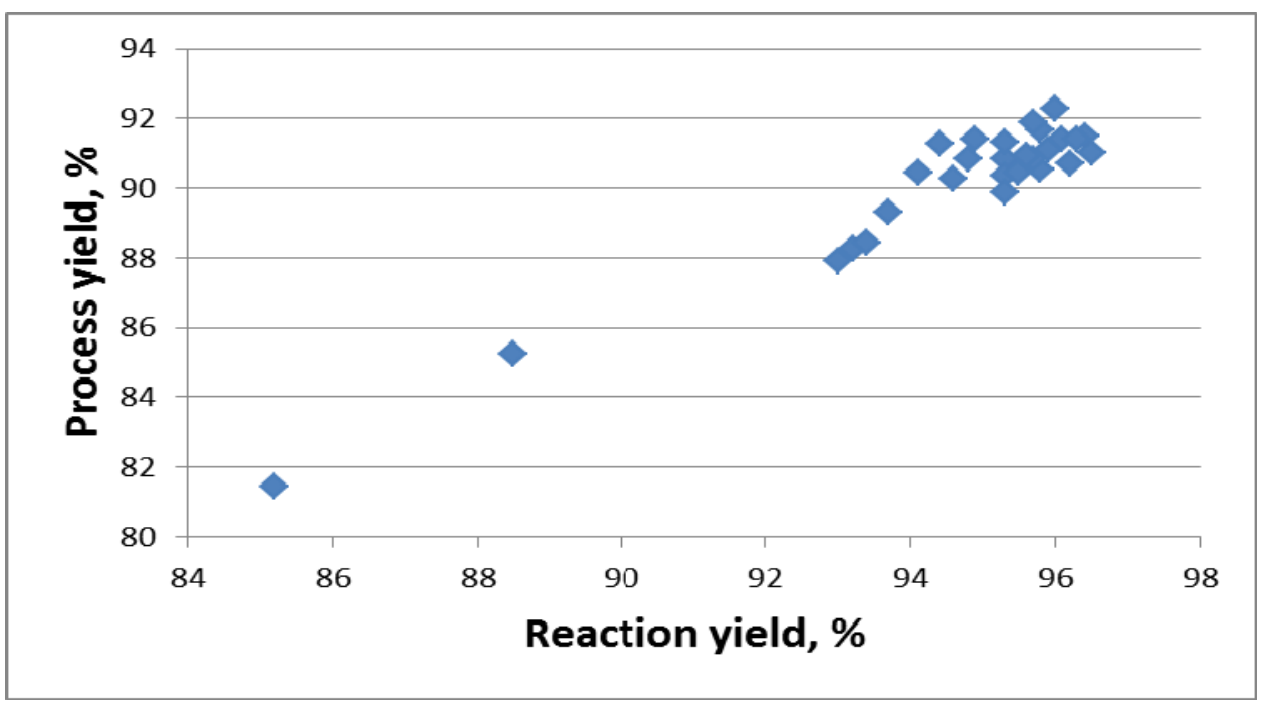

Fig. 2. Correlation between the reaction yield and process yield of transesterification (catalyst - potassium hydroxide) 
On the basis of the reaction yield and process yield correlation we can conclude that the higher limit of linear area in case of potassium hydroxide is approximately $2.5 \mathrm{wt} . \%$ of oil and only in this area it is possible to have the high process yield. The comparison of all correlation parameters for the both investigated catalysts (Table 3 ) allow us to conclude that the activity of both catalysts is approximately the same. The higher slope for sodium hydroxide indicates that in the low catalyst concentration region sodium hydroxide is some more active catalyst than potassium hydroxide, but the difference in linear correlation areas shows that potassium hydroxide is more suitable for the reactions with a high catalyst concentration.

TABLE 3

PARAMETERS OF LINEAR CORRELATION

\begin{tabular}{|l|c|c|}
\hline \multicolumn{1}{|c|}{ Characteristic } & $\begin{array}{c}\text { Sodium } \\
\text { hydroxide }\end{array}$ & $\begin{array}{c}\text { Potassium } \\
\text { hydroxide }\end{array}$ \\
\hline $\begin{array}{l}\text { Linear area of reaction and } \\
\text { process yield correlation, catalyst } \\
\text { concentration wt.\% of oil }\end{array}$ & $0.2-1.5$ & $0.2-2.5$ \\
\hline Correlation coefficient $\left(\mathrm{r}^{2}\right)$ & 0.979 & 0.94 \\
\hline Slope & 0.904 & 0.89 \\
\hline Intercept & 5.2 & 5.725 \\
\hline
\end{tabular}

\section{CONCLUSIONS}

For the characterisation of transesterification reaction of oils and fats in order to produce biodiesel, the determination of two differential experimental characteristics - the reaction yield and the product yield - are necessary. The first characteristic gives the information about the reaction proceeding, but the second includes additional information about the settling, separation and cleaning of the desired product. The analysis of those characteristics for transesterification of a high quality rapeseed oil with methanol in the presence of the two investigated catalysts shows that in the low concentration region sodium hydroxide is the preferable catalyst, while in the high concentration area the most preferable catalyst should be potassium hydroxide.

\section{ACKNOWLEDGEMENTS}

The researchis work was financially supported by the European Social Fund, Project "Scientific Group Supporting Latvian Activities of the European Strategic Energy Technology Plan”, No.1DP/1.1.1.2.0/09/APIA/VIAA/027.

\section{REFERENCES}

1. Ghoniem A.F. (2011) Needs, Resources and Climate Change: Clean and Efficient Conversion Technologies. Progress in Energy and Combustion Science, 37, pp 15-51. http://dx.doi.org/10.1016/j.pecs.2010.02.006

2. Demirbas A. (2008) Biodiesel, Springer-Verlag, London, 208 p.

3. Drapcho C.M., Nhuan N.P. and Walker T.H. (2008) Biofuels engineering process tehnology, McGraw-Hill Companies, New York, $371 \mathrm{p}$.

4. Duz M.Z., Saydut A., Ozturk G. (2011) Alkali Catalysed Transesterification of Sunflower Seed Oil Assisted by Microwave Irradiation. Fuel Processing Technology, 92, pp. 308-313. http://dx.doi.org/10.1016/j.fuproc.2010.09.020

5. Sun J., Caton J.A., Jacobs T.J. (2011) Oxides of Nitrogen Emissions from Biodiesel-fuelled Diesel Engines. Progress in Energy and
Combustion $\quad$ Science, $\quad 36$, http://dx.doi.org/10.1016/j.pecs.2010.02.004.

pp.

677-695

6. Zabeti M., Wan Daud W.M.A., Aroua M.K. (2009) Activity of solid catalysts for biodiesel production: A review. Fuel Processing Technology, 90, pp. 770-777. http://dx.doi.org/10.1016/j.fuproc.2009.03.010

7. Jimenez-Lopez A., Jimenez-Morales I., Santamaria-Gonzalez J., Maireles-Torres P. (2011) Biodiesel production from sunflower oil by tungsten oxide supported on zirconium doped MCM-41 silica. J.Mol.Catal. A: Chemical, 335, pp. 205-209. http://dx.doi.org/10.1016/j.molcata.2010.11.035

8. Encinar J.M., Gonzalez J.F., Pardal A., Martinez G. ( 2010) Rape oil tranesterification over heterogeneous catalysts. Fuel Processing Technology, 91, pp. 1530-1536. http://dx.doi.org/10.1016/j.fuproc.2010.05.034

9. Campanelli P., Banchero M., Manna L. (2010) Synthesis of biodiesel from edible, non-edible and waste cooking oils via supercritical methyl acetate transesterification. Fuel, 89, pp. 3675-3682. http://dx.doi.org/10.1016/j.fuel.2010.07.033

10. Ilgen O. (2011) Dolomite as a heterogeneous catalyst for transesterification of canola oil. Fuel Processing Technology, 92, pp. 452455.

11. Kiss F.E., Jovanovic M., Boškovic G.C. (2010) Economical and ecological aspects of biodiesel production over homogeneous and heterogeneous catalysts. Fuel Processing Technology, 91, pp.1316-1320. http://dx.doi.org/10.1016/j.fuproc.2010.05.001

12. Keera S.T., EI Sabagh S.M., Taman A.R. (2011) Transesterification of vegetable oil to biodiesel fuel using alkaline catalyst. Fuel, 90, pp. 42-47. http://dx.doi.org/10.1016/i.fuel.2010.07.046

13. Demirbas A. (2008) Comparison of transesterification methods for production of biodiesel from vegetable oils and fats. Energy Conversion and Management, 49, pp. 125-130. http://dx.doi.org/10.1016/j.enconman.2007.05.002

14. Sharma Y.C., Singh B. (2009) Development of biodiesel; Current scenario. Renewable and Sustainable Energy Reviews, 13, pp.1646-1651. http://dx.doi.org/10.1016/j.rser.2008.08.009

15. Shuchardt U., Sercheli R., Vargas R.M. (1998) Transesterification of vegetable oils: a review. J.Braz.Chem.Soc., 9, pp. 199-210.

16. Meher L.C., Dharm S.S., Naik S.N. (2006) Optimization of alkalicatalyzed transesterification of Pongamia pinnata oil for production of biodiesel. Bioresource Technology, 97, pp.1392-1397. http://dx.doi.org/10.1016/j.biortech.2005.07.003

17. Soares C.M., Itavo L.C.V., Dias A.M., Eruda E.J., Delben A.A.S.T., Oliveira S.L., de Oliveira L.C.S. (2010) Fuel, 89, pp. 3725-3729. http://dx.doi.org/10.1016/j.fuel.2010.07.024

18. Da Costa Barbosa D., Serra T.M., Meneghetti S.M.P., Menegheti M.R. (2010) Biodiesel production by ethanolysis of mixed castor and soybean oils. Fuel, 89, pp. 883-890.

19. Leung D.Y.C., Guo J. Transesterification of neat and used frying oil: optimization for biodiesel production. (2006) Fuel Processing Technology, 87, pp.1316-1320. http://dx.doi.org/10.1016/j.fuproc.2006.06.003

20. Eevera T., Rajendran K., Saradha S. (2009) Biodiesel production process optimization and characterization to assess the suitability of the product for varied environmental conditions. Renewable Energy, 34, pp. 762-765 http://dx.doi.org/10.1016/j.renene.2008.04.006

Valdis Kampars, Professor, Dr.hab.chem., 1983, the Latvian Academy of Sciences (Doctor of Science in the former USSR). Dr.chem. (Candidate of Science in the former USSR, Ph.D. in Western countries), Riga Technical University, 1974. Riga Technical University (Faculty of Chemistry), cum laude, 1970 .

Since 2008 V.Kampars has been the Secretary General of the Latvian Academy of Sciences.

Since 2002 V.Kampars has been the Head of the Department of Chemistry.

In the period of 2003-2008, V.Kampars was the Dean of the Faculty of Materials Science and Applied Chemistry.

In the period of 1993-2003, V.Kampars was the Dean of the Faculty of Chemical Technology.

In the period of1989-2002, V.Kampars was a Professor at the Department of General Chemistry.

Professional Activities and Memberships:

Vice-president, Latvian Association of University Professors, 1996 onwards;

Chairman, Promotion Council (Organic Chemistry), Riga Technical University, 2000 - onwards; 
Member of the Board, Latvian Chemical Society, 1990 - onwards; Chairman of the Senate, Riga Technical University, 2000 - onwards; Editor-in-Chief, Scientific Proceedings of Riga Technical University, Materials Science and Applied Chemistry.

E-mail: kampars@ktf.rtu.lv

Kristaps Māliṇš. Dr. chem., 2012, Riga Technical University (RTU), the Faculty of Materials Science and Applied Chemistry (FMSAC). Work experience: in the period of 2004-2006, K.Mālinš was a Laboratory Assistant at the Department of Biologically Active Substances (RTU) under the guidance of Dr.habil.sc.ing., Professor E.Gudriniece and Dr.habil.sc.ing., Professor M.Jure. In the period of 2006-2007, K.Mālinš was a Laboratory Assistant at the Institute of Applied Chemistry (RTU) under the guidance of Dr.habil.sc.ing., Professor V.Kampars. Since 2007 K.Mālinš has been a Researcher at the Institute of Applied Chemistry (RTU) under the guidance of Dr.habil.sc.ing., Professor V.Kampars. E-mail: mkrist@inbox.lv
Tatjana Rusakova. Mg.chem., 2010, Riga Technical University (RTU), the Faculty of Materials Science and Applied Chemistry (FMSAC). Since 2010 T.Rusakova has been a Researcher at the Institute of Applied Chemistry, RTU. E-mail: tatjana.rusakova@rtu.lv

Zane Šustere. Mg.chem., 2010, Riga Technical University (RTU), the Faculty of Materials Science and Applied Chemistry. Since 2010 Z.Sustere has been a Researcher at the Institute of Applied Chemistry, RTU. E-mail: zanesustere@inbox.lv

Jānis Brinks. Bachelor's degree student at Riga Technical University (RTU), the Faculty of Materials Science and Applied Chemistry, the study programme "Chemical Technology". Since 2010 J.Brinks has been a Laboratory Assistant at RTU FMSAC, the Institute of Applied Chemistry under the guidance of Dr,chem. K.Māliņš and Dr.habil.sc.ing., Professor V.Kampars. E-mail: janisbrin@gmail.com

Valdis Kampars, Kristaps Māliņš, Tatjana Rusakova, Zane Šustere, Jānis Brinks. Biodīzeḷdegvielas sintēze no rapšu eḷ̦as nātrija un kālija hidroksīdu klātbūtnē

Biodīzel̦degvielas ražošanu veic lipīdu reakcijā ar metanolu vai etanolu katalizatora klātienē , un šīs transesterifikācijas reakcijas iznākumu ietekmē daudzi faktori. Galvenie no tiem ir izejvielas kvalitāte, katalizatora veids un tā koncentrācija, katalizatora un lipīda molārā attiecība, spirta un lipīda molārā attiecība, reakcijas ilgums un temperatūra. Literatūras datu analīze l̦auj secināt, ka neeksistē vispārpieņemti kritēriji šo reakciju un katalizatora darbības novērtēšanai. Veiktie eksperimentālie augstas kvalitātes rapšu ellıas transesterifikācijas reakciju pētījumi, mainot visus reakcijas apstākḷus plašā diapazonā, parādīja, ka ir lietderīgi lietot divus raksturojumus: reakcijas iznākumu un procesa iznākumu, kurus šajā darbā noteicām transesterifikācijas reakcijām nātrija un kālija hidroksīdu klātienē . Abu raksturojumu savstarpēja salīdzināšana sniedz jaunas iespējas piemērotākā katalizatora izvēlei, lai konkrētos apstākḷos realizētu reakciju ar maksimāli lielu produkta ieguvi. Neskatoties uz abu katalizatoru aptuveni vienādo aktivitāti, tie atšķirīgi ietekmē glicerīna un el̦ıas slāņu atdalīšanu. Augstas kvalitātes izejvielas gadījumā, kad procesu var veikt mazu katalizatora daudzumu klātienē , izdevīgāk ir lietot nātrija hidroksīdu. Ja nepieciešams lietot palielinātus katalizatora daudzumus, tad priekšroka dodama kālija hidroksīdam. Nepieciešamo katalizatoru daudzumu nosaka brīvo taukskābju daudzums izejvielā, kas neitralizē daļu no ievadītā katalizatora.

Валдис Кампарс, Кристапс Малиньш, Татьяна Русакова, Зане Шустере, Янис Бринкс. Синтез биодизельного топлива в присутсвии гидроксидов натрия и калия.

Производство биодизельного топлива осуществляется метанолизом или этанолизом липидов, а эффективность процесса зависит от множества различных факторов влияющих на реакцию трансэстерификации. Важнейшими из этих факторов являются: качество растительного масла, тип катализатора и его концентрация, молярное отношение катализатора и масла, температура и продолжительность реакции. Литературные исследования показали, что не существует общепринятых характеристик реакций трансэстерификации и катализаторов. Экспериментальные исследования реакций трансэстерификации высококачественного рапсового масла при вариации условий в широких пределах позволили нам выделить две разные характеристики: выход реакции и выход процесса, определения которых в данной работе проведены для реакций в присутствии катализаторов едкого калия и едкого натрия. Сопоставление величин определенных характеристик дает новый критерий для выбора оптимального катализатора, для проведения реакций в конкретных условиях с максимальным количеством продукта. Несмотря на приблизительно одинаковую активность исследованных катализаторов, они по-разному влияют на эффективность отделения слоев биодизеля и глицерина. Поэтому при использовании малого количества катализатора преимущество имеет едкий натрий, а при использовании большого количества катализатора - едкий калий. Количество катализатора, необходимого для успешного проведения реакции трансэстерификации, в основном зависит от содержания свободных жирных кислот в растительном масле. 